\title{
A NEW STELE BASE OF THE LATE HITTITE PERIOD FROM SIVEREK-ŞANLIURFA
}

\section{Bahattin ÇELİK}

\begin{abstract}
A new stele base dedicated to the Storm God has been found at Haçgöz (Yeşilçat) village in the township of Siverek, Şanlıurfa. The base bears a Hittite hieroglyphic inscription on its rear side and this is the second hieroglyphic inscription of the Late Hittite Period found in Şanliurfa province. It is generally accepted among the scholars that the Siverek region had an important place in the Late Hittite geography. It is thought that the decipherment of the inscription on this new find will contribute greatly to the geography of the period.
\end{abstract}

Recent surveys in the province of Şanliurfa and the works at the Şanliurfa Museum point to the fact that the Late Hittite finds from the region are quite extensive ${ }^{1}$.

1 "The Moveable and Immoveable Cultural Heritage Inventory of East and Southeast Anatolia Project" was conducted under the direction of Prof. Dr. Abdüsselam Uluçam with the financial support of Turkish Historical Society and State Planning Organisation from 1999 to 2003 . Within the frame of the abovementioned project, the inventory project of Şanliurfa was carried out by Asst. Prof. Dr. Cihat Kürkçüoğlu, Head of the Department of Archaeology of Harran University, and Research Asst. Bahattin Çelik under the direction of Prof. Uluçam. The inventory surveys brought to light numerous new archaeological sites and the works of art found were turned over to the Şanliurfa Museum. During these surveys, a stele base, which forms the scope of this article, was discovered in the village of Haçgöz (Yeşilçat) in the township of Siverek. Besides, a survey on the Late Hittite Period was conducted by Prof. Dr. Fikri Kulakoğlu from 1998 to 2001. Prof. Kulakoğlu also found new works of art dating to the 1 st millennium $\mathrm{BC}$ at sites such as Gölpınar, Kabahaydar-Edene/Gürpınar, Külaflı Tepe, town centre of Siverek, MehmedihanAşağ1 Seyek, Hilvan-Aslanl,, town centre of Şanlıurfa, Haçgöz, Harran, Til Hinta and Kap village. For more information on these finds, see
Some of the works in question had been sent to the Museums of Adana, Istanbul and Ankara prior to the establish-ment of the Archaeological Museum at Şanliurfa in $1968^{2}$. The Siverek township of Şanlıurfa as

Kulakoğlu 1999: 167-181; 2000: 1-5; 2001a: 57-66; 2001b: 27-33; 2003: 65-87.

2 At Adana Museum, the provenance of the work with Inv. Nr. 1646 is registered as an area between Zeynep and Til Ambar (Telanbar / Ambartepe) villages in the district of Yardımcı near Şanlıurfa town centre. This piece recalls the orthostats of Carchemish and it bears a depiction of warrior figures, riding a chariot and shooting an arrow. Kurt Bittel mentions that another piece of the same item was housed at the Directorate of Education at Urfa at that time. For more information see Bittel 1949: 284-285, fn. 2; Orthmann 1971: 537; Ussishkih 1975: 88, P1. 16.1.

At Istanbul Archaeological Museums, the works with Inv. Nr. 4788 and 4789 are registered with the provenance as Taşlı village in the district of Karakeçi in the township of Siverek, Şanlıurfa. One of these works is a stele dedicated to the Storm God and the other is a relief depicting a cone in the middle flanked with a seated figure wearing a long robe on each side. For more information see Ongunsu 1943: 688-693, Fig.s 1-4; Seidl 1989: 456, Fig.s 1-2, Pl.132: 1, 2, 3.

At Arkara Museum of Anatolian Civilisations, the work with Inv. Nr. 11242 is a stele dedicated to the 
not been surveyed extensively; however, some works found at Taşlı village of Siverek were sent to Istanbul Archaeological Museums in 1942 and these works were then published $^{3}$. Recent surveys by Kulakoğlu paved the way leading to interesting results regarding the Late Hittite Period of the region ${ }^{4}$. These surveys identified new settlements like Siverek town centre and Haçgöz (Yeşilçat) in Siverek township, which might be dated to the Late Hittite Period ${ }^{5}$.

Haçgöz village of Siverek is an already identified settlement ${ }^{6}$. First informing ${ }^{7}$ came to the Museum of Şanliurfa in 1979 and a basalt block of $3.10 \times 2.26 \times 0.54$ meters with an incomplete carving of a lion was found at an Late Hittite sculpture workshop identifed in this village ${ }^{8}$. The information on this site was passed on to the scholars by

Storm God and brought from Anaz (Duru) village in the district of Chamlidere in the central township of Şanlıurfa. For more information see Çambel 1950: 251, Taf. XXIV, Abb. 29; Bittel 1949: 285, fn.2; Bossert et al 1950: Abb. 156, 158; Alk1m 1952: 244; Orthmann 1971: 479. Another stele displayed in the courtyard of the museum bears a Semitic inscription and was found by Pognon at the same village. Pognon had the inscription deciphered and identified the village of Anaz as ancient Duru. See Pognon 1907: 106-107, Planche V; Forrer 1920: 22. Besides, the Yaylak stele with Inv. Nr. 11244 bearing a Semitic inscription and Aligör stele are also housed at this museum. For more information see Yağc1 1995: 380, Fig. 3; BörkerKlähn 1982: 221-222, Abb, 240a - 240b; Kulaçoğlu 1992: 133, No. 153; Blochner 2001: 46-47, Taf. 5.

3 It is mentioned that both of these works were sent to Istanbul by Ekrem Yalçınkaya, the Deputy Governor of the time on 10 July 1942. See Ongunsu 1942: 688, Fig.s 1 and 4; Özgültekin et al 2003: 46.

4 Kulakoğlu 2003, 71-73.; Köroğlu 1998, 81-85.

5 Kulakoğlu 2000, 3; 2001a, 58-59; 2001b, 31; 2003: 71, 73 .

6 Haçgöz is a village in the district of Şekerli in the township of Siverek. Also see Kulakoğlu 2003: 3, Fig. 13.

7 Private interview with Asst. Prof. Dr. Cihat Kürkçüoğlu.

8 Kulakoğlu 2000: 3.
Eyyüp Bucak, the director of Şanlıurfa Museum, during their surveys covering the 1st millennium $\mathrm{BC}$ of the region?.

The stele base to be introduced here was uncovered during foundation excavations to build a house about 30 meters northeast of the mound (höyük) in Haçgöz village ${ }^{10}$. The stele measures $0.72 \mathrm{~m}$ in height by $0.82 \mathrm{~m}$ in width and $1.11 \mathrm{~m}$ in length. It is decorated with bull depictions in relief. The heads of both bulls and the bull on the left were entirely destroyed. The bull on the right and the five-line hieroglyphic inscription on the rear side - though its upper left corner broken - have survived partially (Figure 1). Only the hooves of the bull on the left can be discerned from the front (Figure 2). The hole on the top of the stele, where probably a statue was mounted, has been preserved partially and measures $0.24 \mathrm{~m}$ long as preserved and ca. $0.15 \mathrm{~m}$ deep (Figure 3). The better-preserved bull figure on the right has a hole of $0.30 \mathrm{~m} \times 0.20 \mathrm{~m}$ and $0.25 \mathrm{~m}$ deep in its belly indicating a second phase of use (Figure 4). The author is of the opinion that most of the missing parts originate from the second phase of use.

The carving on the base is separated from the ground with a platform of ca. $1-1.5 \mathrm{~cm}$ in thickness. The better-preserved bull figure was carved in low-relief technique and its fore-limb joins the body outlined with a molding in the shape of a kidney. Its tail ends in a guilloche motif whereas its hind legs' muscles are outlined with a long groove along the rear side. The testicles are depicted almost round while the genital organ is given linearly. The hooves of the bull are depicted together with the proximal

9 Kulakoğlu 2000: 3; 2001a: 58.

10 Interview with İbrahim Alpan, a native of Haçgöz village. 
sesamoid bones ${ }^{11}$. The proximal sesamoid bones are in profile on the right side, but they are again depicted in profile on the front side of the base; however, all the other organs are given in frontal view on the front side of the base (Figure 2). On the front side, there are four legs, clearly discernible, belonging to two bulls. One leg of each bull is given stepping forward. The hooves of the fore-limbs stepping forward are outlined clearly with a groove.

As mentioned above, the foremost eyecatching feature of the bull depiction is the muscle group joining the fore-leg to the body. Parallel examples are found at Gölpınar in Şanlıurfa ${ }^{12}$, Arslantaş ${ }^{13}$ and Zincirli $^{14}$. Based on the stylistic parallelism with these examples, it is possible to date the Haçgöz stele base to the Late Hittite II phase $^{15}$.

Besides, the tail ending in guilloche is a feature unparalleled in the region, to the best of the author's knowledge. However, such guilloche motifs are found extensively in Anatolia and Mesopotamia and in the 1st millennium $\mathrm{BC}$, they are generally seen along the upper or the lower borders of the orthostats. Among similar examples can be cited almost all the upper and lower border decorations from the Carchemish orthostats $^{16}$, the lower border of a stele dedicated to the Storm God found at Till Barsib $^{17}$, the lower border of a Lamassu

11 Proximal sesamoid bone is a small toe, atrophied, right behind the hooves of the herbivorous animals. Anatomical Atlas 1994: 19.

12 Kulakoğlu 1999: Pl.2.

13 Thureau-Dangin et al 1931: Pl. II.3.

14 Orthmann 1971: Taf. 58b, 60b, 60e, 62a, 62c.

15 Orthmann 1971: 31, 504, 543; Kulakoğlu 1999: 169.

16 Orthmann 1971: Taf. 24a-d, 24f, 25 d.

17 Thureau-Dangin et al 1939: P1.III. recovered at Aslanlı village of Siverek ${ }^{18}$, and the examples from Zincirli ${ }^{19}$ and Sakçagözü ${ }^{20}$.

The so-called "Demirci Way" by Köroğlu is presented as an alternative way to the present modern road between Urfa and Siverek $^{21}$. This way was documented by Matrakçı Nasuh, who depicted the Iraqi campaign route by Süleyman the Magnificent in the 16th century ${ }^{22}$. This source shows us an alternative route starting from Diyarbakır, passing through Karacadağ, Haçgöz, Elmalı, Cullap/Edene and reaching Urfa. This route is $20-25 \mathrm{~km}$ shorter than the present Urfa-Siverek road and it is thought that it was in use during the Late Hittite Period as inferred from the presence of numerous mounds and several bridges dating to the Antiquity in the region ${ }^{23}$.

Haçgöz, Siverek town centre and Taşlı settlements, all close to each other and in Siverek township today, are likely to have been cities of the Izala (Izalla) Land ${ }^{24}$. It is known that the Izala Land paid taxes to Ashurnasirpal II during his 2nd and 10th campaigns, and it must be located between the present-day Siverek and Karacadag regions as claimed by Liverani ${ }^{25}$. It is also known that there existed 8 settlements in the Izala Land and some of these sites are mentioned in the inscriptions ${ }^{26}$.

18 Kulakoğlu 2000: Fig. 12; 2001b, Fig. 10; 2003: Fig.13.

19 Orthmann 1971: Taf. 63g.

20 Orthmann 1971: Taf. 51b-e.

21 Köroğlu 1998: 81-85.

22 Yurdaydın 1976: 108-110.

23 Köroğlu 1998: 75, 79, 81-85, Fig. 18.

24 Postgate 1976-1980: 225-226.

25 Liverani 1992: 34, 44, 81, Fig.s 3, 9, 11.

${ }^{26}$ Forrer cites Anduli, Ashihi, Kashpi, Iadi, Barzanishta and Til Zani settlements in the Izala Land (1920: 22) while Falkner adds Absijai and Ispallure to them (1958: 15). 
The Haçgöz stele base of the Storm God should be dated as of the second quarter of the 9th century BC in regards to the history of the region ${ }^{27}$. Such dating is also supported with the decorative style ${ }^{28}$. Besides, the hieroglyphic inscription on it, being the second one from the region after the other inscribed stele base from Külaflı Tepesi ca. 5 $\mathrm{km}$ north of Şanliurfa, further supports this dating $^{29}$. It is of great worth noting that these two inscriptions are the first non-Semitic ones from the region, other than the Semitic inscriptions from Anaz and Yaylak ${ }^{30}$. The present paper aims at only introducing this important find to the academic world. All the Late Hittite Period works and hieroglyphs found in Şanliurfa region up to the present will be evaluated and published together in the near future.

\section{Dr.Bahattin Çelik,}

Hacettepe Üniversitesi, Edebiyat Fakültesi, Arkeoloji Bölümü, Beytepe/Ankara

bcelik@hacettepe.edu.tr

\section{List of Figures}

Figure 1: The rear side of the Haçgöz stele base bearing the hieroglyphic inscription.

Figure 2: Front side of the Haçgöz stele base. Figure 3: Upper side of the Haçgöz stele base.

Figure 4: Right hand side of the Haçgöz stele base.

27 Kulakoğlu 2003: 75.

28 Orthmann 1971: 31, 504, 543.

29 Kulakoğlu 2003: 70, 76.

30 See footnote 2. 


\section{Kaynakça / References}

Anatomical Atlas 1994

Bittel 1949

Blocher 2001

Börken-Klähn 1982

Falkner 1958

Forrer 1920

Köroğlu 1998

Kulaçoğlu 1992

Kulakoğlu 1999

Kulakoğlu 2000

Kulakoğlu 2001a

Kulakoğlu 2001b

Kulakoğlu 2003

Liverani 1992

Ongusu 1943

Orthmann 1971

Özgültekin et al 2003

Pognon 1907
Pfeizer Animal Health Group, New York, (1994).

K.Bittel, "Nur hethitische oder auch hurritische Kunst?" Zeitschrift für Assyriologie (Neue Folge), Band 15 (Band 49), (1949): 256-290.

F.Blocher, "Nachlese zur Ikonographie des Mondgottes Nabonids Stele aus Harran,” Eds. R. Boehmer M. \& J. Maran, Archaeologie zwischen Asien und Europa, Festschrift für Harald Hauptmann, (2001): 45-48.

J.Börken-Klähn, Altvorderasiatische Bildstelen und vergleichbare Felsreliefs. Berlin (1982).

M.Falkner, Archiv für Orientforschung (AOF), 18, (1957-1958): 1-37.

E.Forrer, Die Provinzeinteilung des assyrischen Reiches, Leipzig, (1920).

K.Köroğlu, Üçtepe I: Yeni Kazı ve Yüzey Bulguları Işı̆̆ında Diyarbakır / Üçtepe ve Çevresinin Yeni Assur Dönemi Tarihi Coğrafyası, T.T.K. Yayınları, Series V, Nr. 45, Türk Tarih Kurumu Basımevi, Ankara, (1998).

B.Kulaçoğlu, Museum of Anatolian Civilisations: Gods and Goddesses, Ankara, (1992).

F.Kulakoğlu, "Late-Hittite Sculptures from Şanlıurfa Region." Bulletin of the Middle Eastern Culture Center at Japan. Vol. XII, (1999): 167-181.

F.Kulakoğlu, "Şanlıurfa M.Ö. I. Bin Merkezleri Yüzey Araştırması" 17. Araştırma Sonuçları Toplantısı, Vol.2, T.C. Kültür Bakanlığı Anıtlar ve Müzeler Genel Müdürlüğ̈̈, 24-28 Mayıs 1999, Kültür Bakanlığı Milli Kütüphane Basımevi, Ankara, (2000): 1-5.

F.Kulakoğlu, "Şanlıurfa M.Ö. I. Binyıl Merkezleri Yüzey Araştırması" 18. Araştırma Sonuçları Toplantısı, Vol.2., T.C. Kültür Bakanlığı Anıtlar ve Müzeler Genel Müdürlüğü, 24-28 Mayıs 1999, Kültür Bakanlığ1 Milli Kütüphane Basımevi, İzmir, (2001): 57-66.

F.Kulakoğlu, "Şanlıurfa Bölgesinde Yeni Keşfedilen M.Ö. I. Binyıl Heykeltıraşlık Eserleri” Türkiye Arkeoloji ve Etnografya, No. 2, T.C. Kültür Bakanlığı Anttlar ve Müzeler Genel Müdürlüğü Yayınları No. 81, Kültür Bakanlığı Milli Kütüphane Basımevi, Ankara, (2001): 27-34.

F.Kulakoğlu, "Şanlıurfa'da Son Yıllarda Keşfedilen Geç Hitit heykeltıraşlık Merkezleri ve Eserleri.", 2002 Yılı Anadolu Medeniyetleri Müzesi Konferansları, T.C. Kültür Bakanlığı Anıtlar ve Müzeler Genel Müdürlüğü, Anadolu Medeniyetler Müzesi, Ankara, (2003): 65-87.

M.Liverani, Studies on the Annals of Ashurnasirpal II- 2:Topographical Analysis, Quaderni di Geografika Storica, 4, Roma, (1992).

N.Ongunsu, "Siverek Taşlıköy’de Bulunmuş iki stel," III. Türk Tarih Kongreleri, Kongreye Sunulan Tebliğler, TTK Basımevi, (1943): 688-693.

W.Orthmann, Untersuchungen zur Späthethitischen Kunst, Rudolf Habelt Verlag, Bonn, (1971).

R.Özgültekin et al., Tarihi ve Kültürüyle Siverek, Siverek Kaymakamlığ Yayınları No: 4, Tisamat Basım Sanayi, Ankara, (2003).

H.Pognon, Inscriptions Sèmitiques de la Syrie, de la Mèsopotamie et de la region de Mossoul, (1907). 
Postgate 1976-80

Seidl 1989

Yurdaydın 1976

Ussishkin 1975

Yağcı 1995
J.N.Postgate, "Izalla," Reallexikon der Assyriologie und Vorderasiatischen Archaeologie, Fünfter Band, Walter de Gruyter, Berlin-New York, (1976-1980): 225-226.

U.Seidl, "Zwei Frühdynastische Relief aus dem Vilayet Urfa," Anatolia and Ancient Near East Studies in Honor of Tahsin Özgüç, Ed. K. Emre \& M. Mellink \& B. Hrouda \& N. Özgüç, Ankara, (1989): 455-459.

Thureau-Dangin et al 1931 F.Thureau-Dangin et al., Arslan-Tash, Texte ve Atlas, Paris, (1931).

Thureau-Dangin et al 1939 F.Thureau-Dangin et al., Til-Barsip, Texte und Album, Paris, (1939).

D.Ussishkin, "Three Unpublished Neo-Hittite Stone Monuments," Tel Aviv, Vol. 2, (1975): 86-90.

R.Yağcı, “Ankara Anadolu Medeniyetler Müzesindeki Tanrı Adad Betimlemeli Bir Grup Eser," Eski Yakındoğu Kültürleri Üzerine Incelemeler, In Memoriam I. Metin Akyurt Bahattin Devam Anı Kitabı. (Eds.) A. Erkanal ve H. Erkanal et al. Arkeoloji ve Sanat Yayınları, İstanbul, (1995): 373-387.

H.G.Yurdaydın (Ed.), Nasühü's-Silahi (Matrakçı), Beyan-ı Menazil-i Sefer-i Irakeyn-i Sultan Süleyman Han, Ankara, (1976). 


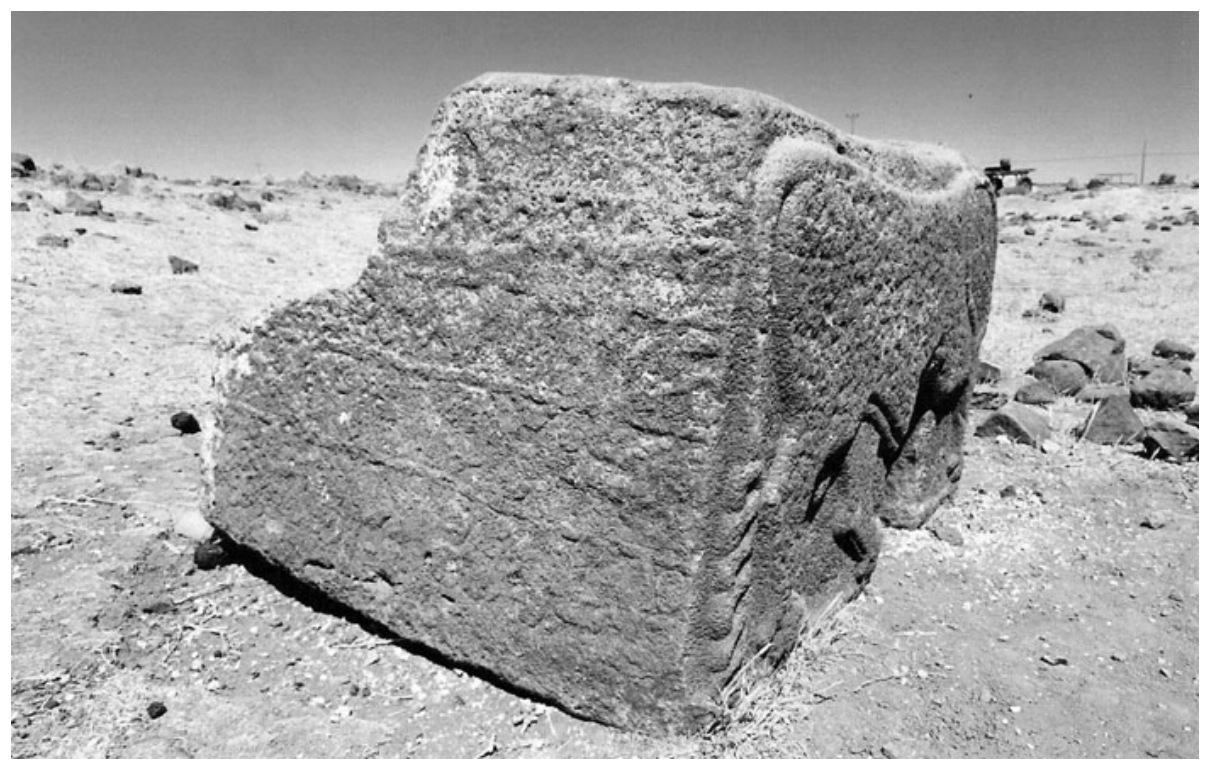

Figure 1

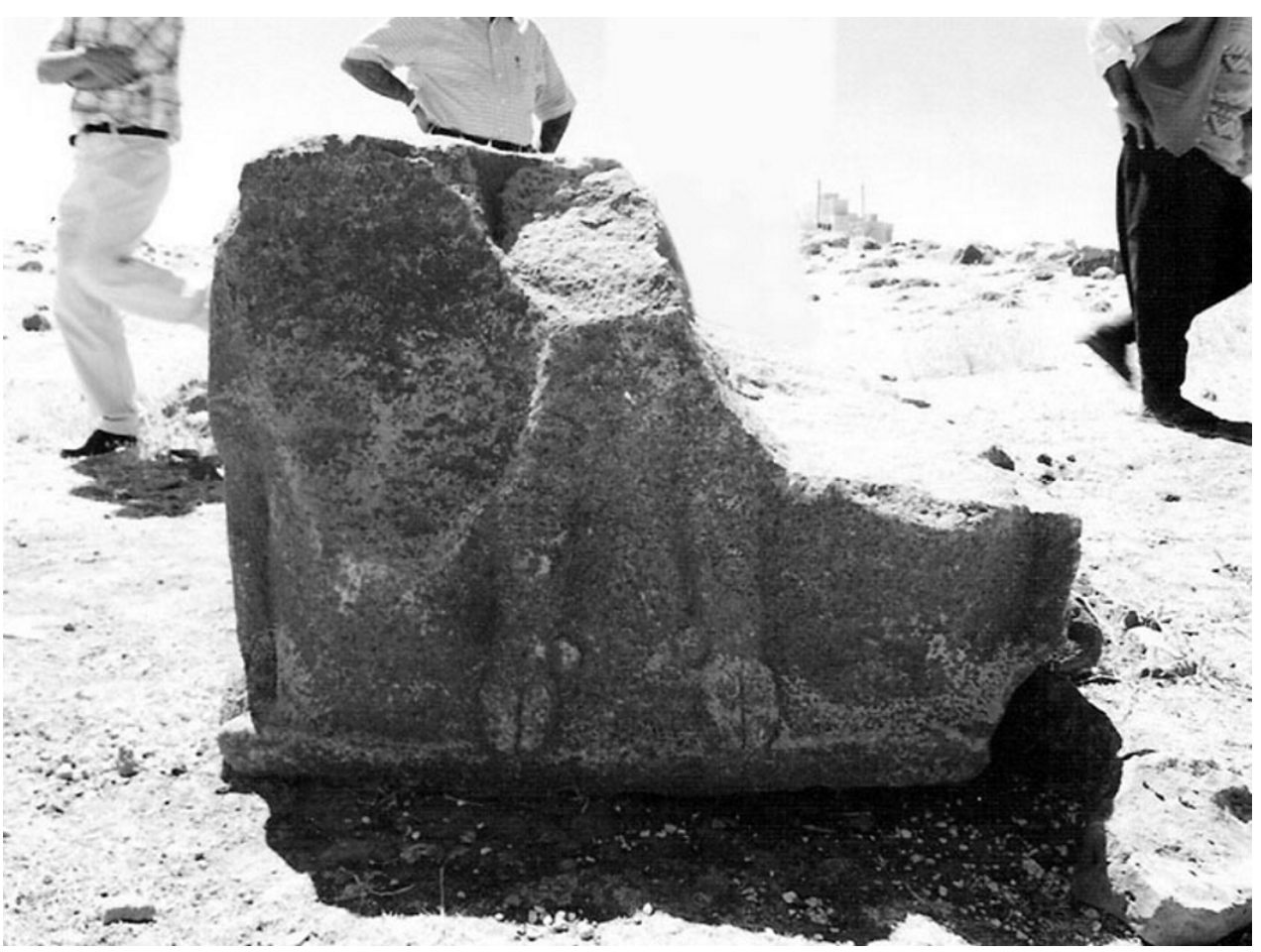

Figure 2 
A New Stele Base of the Late Hittite Period from Siverek-Şanliurfa

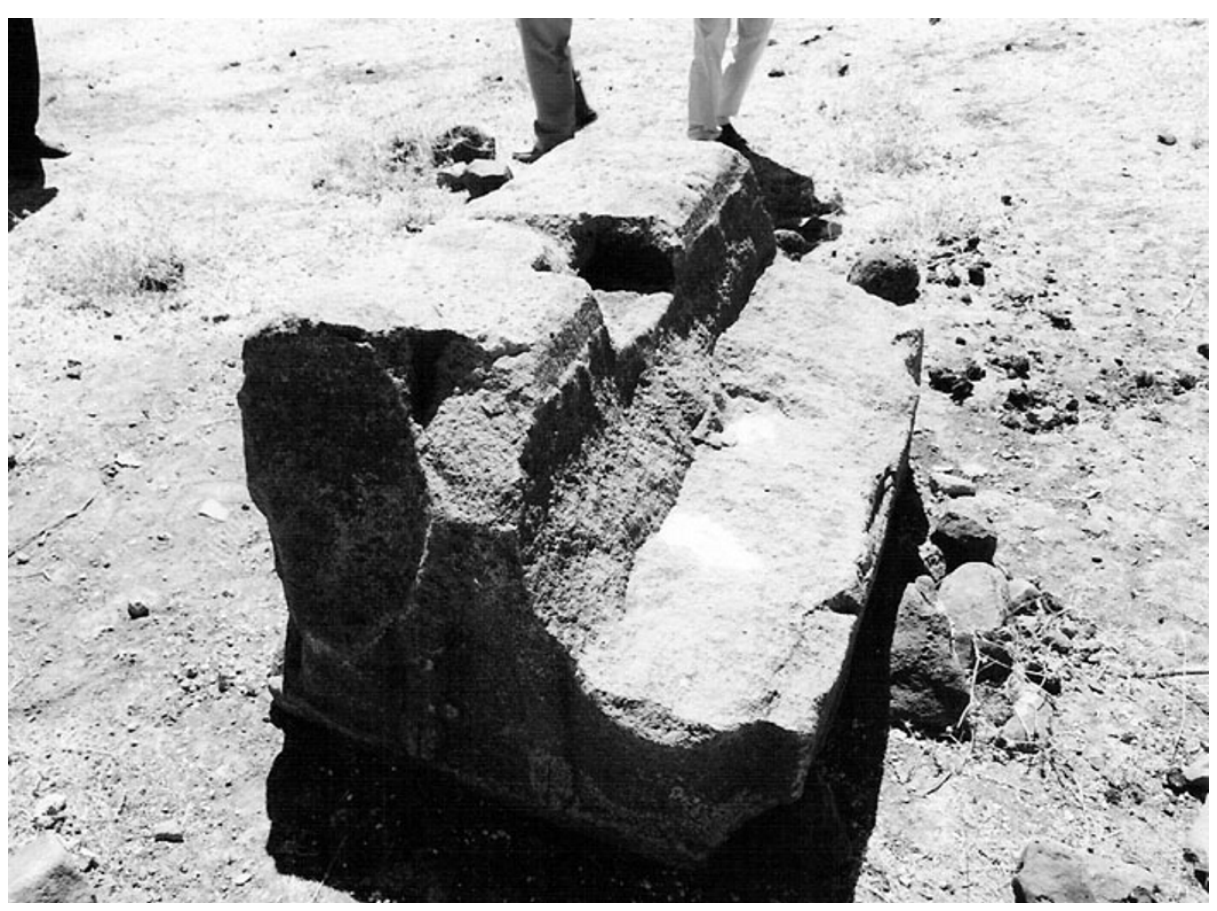

Figure 3

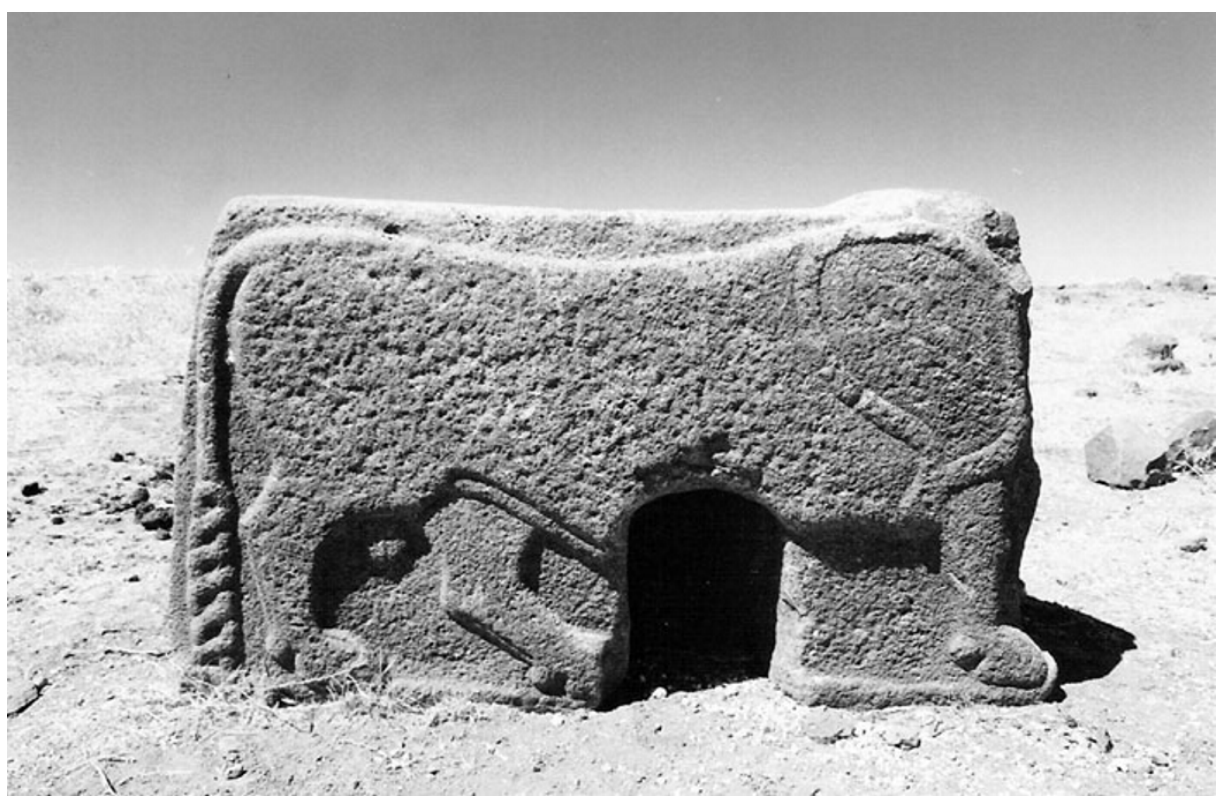

Figure 4 